\title{
Milk composition in the plains viscacha (Lagostomus maximus)
}

\author{
Jane A. Goode, M. Peaker* and Barbara J. Weir †† \\ A.R.C. Institute of Animal Physiology, Cambridge CB2 4AT and $\dagger$ Department of Anatomy, \\ University of Cambridge, Cambridge CB2 $3 D Y$, U.K.
}

\begin{abstract}
Summary. Milk samples were taken from 10 plains viscacha between 9 and 64 days post partum. Mean concentrations ( \pm s.e.) were $17 \pm 1.1 \mathrm{mM}-\mathrm{Na} ; 32 \pm 1.6 \mathrm{mM}-\mathrm{K}$; $35 \pm 2.2 \mathrm{mM}-\mathrm{Cl} ; 116 \pm 3.3 \mathrm{~mm}$-lactose (total reducing sugar) (all in 8 samples); $<10-220 \mathrm{mg}$ citrate/l (range of 4 samples); $15.7 \pm 0.64 \mathrm{~g}$ total nitrogen/l (3 samples). The $\mathrm{Na}: \mathrm{K}$ ratio was $1: 1.95 \pm 0.17$. It was estimated that the fat concentration was between 116 and $182 \mathrm{~g} / \mathrm{l}$.
\end{abstract}

\section{Introduction}

A systematic study of milk composition has been made in very few non-domestic animals; in fewer still have studies been made on the composition of the aqueous phase. Such data are important because they permit examination of whether mechanisms proposed to account for milk secretion can apply to all species with but relatively minor quantitative differences (see Peaker, 1977).

The present study was therefore undertaken on the plains viscacha (Lagostomus maximus), which although indigenous to Argentina has bred successfully in captivity (Weir, 1970). In this caviomorph rodent two relatively precocious young are born $(>90 \%$ of litters) after a gestation of approximately 154 days. There are two pairs of mammary glands situated laterally on the thorax but suckling appears to be confined to the anterior pair. The young appear to suck for several weeks, and sometimes for several months, after parturition but the length of lactation has not been determined. Although some animals may show an immediate post-partum oestrus, there is a lactational anoestrus of $55.9 \pm 3.7$ (s.e., $N=41$ ) days (Weir, 1971). There is no obvious seasonality of breeding in captivity.

\section{Materials and Methods}

Ten animals were used from the colony kept in the Department of Anatomy, University of Cambridge (natural lighting, $18^{\circ} \mathrm{C}$ ). Litter size was 2 in 8 animals and 1 in 2 . The mothers were separated from their young for approximately $2 \mathrm{~h}$ and then lightly anaesthetized with halothane in $\mathrm{O}_{2}$ (open-circuit). The glands chosen for milking were those that were, from the appearance of the nipples, being sucked. The milk was obtained by gentle hand-milking (Goode \& Taylor, 1974) after the administration of oxytocin (Syntocinon; Sandoz Products, 99 The Centre, Feltham, Middlesex) (50 mU into the radial vein) until a sample of approximately $2 \mathrm{ml}$ had been obtained. It would probably have been possible to obtain larger samples of milk by extending the

* Present address and address for reprint requests: The Hannah Research Institute, Ayr KA6 5HL, U.K.

$\ddagger$ Present address: Journal of Reproduction \& Fertility, 22 Newmarket Road, Cambridge CB5 8DT, U.K. 
period of separation from the young, by increasing the dose of oxytocin and by more vigorous manipulation. However, for studies on the composition of the aqueous phase of milk such procedures are, without preliminary trials, hazardous in that they may lead to changes in composition (Peaker, 1977). In rabbits, $100 \mathrm{mU}$ oxytocin may safely be given i.v. to aid the collection of milk (Linzell, Peaker \& Taylor, 1975).

The 10 animals were milked at $9,10,11,12,15,25,49,53,59$ and 64 days after parturition (each animal was milked only once in view of possible long-term effects of oxytocin-Linzell et al., 1975). Samples from the animals milked at 49 and 53 days were bulked, as were those at 59 and 64 days.

Samples were stored at $+4^{\circ} \mathrm{C}$ until analysis several hours after collection. The 8 samples were analysed for $\mathrm{Na}, \mathrm{K}, \mathrm{Cl}$ and reducing sugar (expressed as lactose equivalents) in an autoanalyser as described by Fleet, Linzell \& Peaker (1972). When sufficient milk was obtained $(>2 \mathrm{ml}$ ) citrate (samples at Days 9, 10, 25, 49 and 53) and total nitrogen (Days 10, 25, 49 and 53) were determined by the methods described by White \& Davies (1963) and Linzell (1967) respectively; protein was estimated as total nitrogen $\times 6.38$. In addition an estimate of fat concentration ('rapid' fat) was made by measurement of the column of fat after centrifugation (Fleet \& Linzell, 1964) (Days 10, 25, 49 and 53).

Insufficient volumes of milk were obtained to determine true fat or protein patterns. The 'rapid' fat values calculated require the use of a correction factor obtained from calibration curves for each species between true fat and 'rapid' fat. In 14 species, this correction factor varied from 0.58 to 0.79 (Linzell \& Fleet, 1969). Therefore 'rapid' fat values have been corrected by both factors to indicate the likely range of true fat concentration.

Table 1. Mean \pm s.e.m. concentrations of some components in the milk of the plains viscacha

\begin{tabular}{|c|c|c|}
\hline & Mean $\underset{\text { (range) }}{ \pm \text { s.e.m. conc. }}$ & $\begin{array}{c}\text { No. of } \\
\text { determinations }\end{array}$ \\
\hline $\mathrm{Na}(\mathrm{mM})$ & $17 \pm 1 \cdot 1 \quad(12-21)$ & 8 \\
\hline $\mathrm{K}(\mathrm{mM})$ & $32 \pm 1.6 \quad(25-39)$ & 8 \\
\hline $\mathrm{Cl}(\mathrm{mm})$ & $35 \pm 2 \cdot 2 \quad(28-47)$ & 8 \\
\hline 'Lactose' (mм)† & $116 \pm 3 \cdot 3(105-132)$ & 8 \\
\hline $\mathrm{K} / \mathrm{Na}$ & $1.95 \pm 0.17(1.33-2.92)$ & 8 \\
\hline Citrate $(\mathrm{mg} / \mathrm{l})$ & $\ddagger 70 \pm 50 \cdot 5(<10-220)$ & 4 \\
\hline Total nitrogen $(\mathrm{TN})(\mathrm{g} / \mathrm{l})$ & $15.7 \pm 0.64(14.7-16.9)$ & 3 \\
\hline Estimated protein $(\mathrm{TN} \times 6.38)(\mathrm{g} / \mathrm{l})$ & $100 \pm 4 \cdot 1 \quad(94-108)$ & 3 \\
\hline Estimated fat $\S(\mathrm{g} / \mathrm{l})$ & (116-192) & 3 \\
\hline
\end{tabular}

* See text for details of samples.

$\dagger$ Reducing sugars as lactose equivalents.

$\ddagger$ Calculated assuming values of $\angle 10=10$.

$\S$ See text.

Table 2. Relations between concentrations of some components in the milk of the plains viscacha

\begin{tabular}{lccc}
\hline$x$ & $y$ & $r$ & Regression equation \\
\hline $\mathrm{Na}$ & 'Lactose' $\dagger$ & +0.017 (NS) & $y=115.2+0.05 x$ \\
$\mathrm{~K}$ & 'Lactose' & +0.373 (NS) & $y=90 \cdot 7+0.79 x$ \\
$\mathrm{Cl}$ & 'Lactose' & +0.505 (NS) & $y=89.6+0.76 x$ \\
\hline
\end{tabular}

NS $=$ not significant.

* Least-squares linear regression analysis.

$\dagger$ Reducing sugars as lactose equivalents. 


\section{Results}

There was no apparent tendency for the concentrations of $\mathrm{Na}, \mathrm{K}, \mathrm{Cl}$ or lactose to change with advancing lactation. Therefore, the data from all samples have been bulked and are shown in Table 1. Relationships between $\mathrm{Na}, \mathrm{K}, \mathrm{Cl}$ and lactose are shown in Table 2 .

\section{Discussion}

Within the hystricomorph rodents, reported values for milk protein concentration vary from 47 $\mathrm{g} / 1$ in the acouchi (Myoprocta pratti) to $137 \mathrm{~g} / 1$ in coypu (Myocastor coypus), and for fat from $60-100 \mathrm{~g} / \mathrm{l}$ in the guinea-pig (Cavia porcellus) to $279 \mathrm{~g} / 1$ in the coypu (see Jenness, 1974; Mepham \& Beck, 1973; Peaker, Jones, Goode \& Linzell, 1975). Clearly the viscacha falls within these ranges.

Two aspects of the milk composition are of particular interest. Firstly, the ionic composition is unlike that of most other mammals that have been studied in that the $\mathrm{Na}: \mathrm{K}$ ratio is approximately $1: 2$ and not $1: 3$ (Peaker, 1977). In other species (rabbit: Peaker \& Taylor, 1975) and conditions in which the ratio is lower than about $1: 3$, it has been suggested that paracellular movements of ions and small molecules occur across the mammary epithelium, partly to dissipate concentration gradients established by transcellular processes; evidence from permeability studies supports this view (see Peaker, 1977, 1978). However, this is not necessarily the explanation for the viscacha. Chalk \& Bailey (1979) found an $\mathrm{Na}: \mathrm{K}$ ratio of approximately $1: 1$ in a thorough study of milk composition in the rat. However, one of the indications of the presence of a paracellular pathway, a positive correlation between lactose and $\mathrm{K}$ (since the concentrations of lactose and $\mathrm{K}$ are higher in milk than in blood, they tend to pass out of milk together via a paracellular route), was not obtained in their study; instead a significant negative correlation was obtained. We have insufficient data for a similar definitive analysis in the viscacha, except for an indication of a positive correlation between $\mathrm{K}$ and lactose (Table 2), but if a paracellular pathway is not present in the rat and viscacha then it must either be assumed that the $\mathrm{Na}: \mathrm{K}$ ratio is lower in the mammary secretory cell of these species than in many others, or that additional transport mechanisms are involved, i.e. the hypothesis for transcellular ion movements proposed by Linzell \& Peaker (1971a, b) must be modified for these species. Clearly, physiological studies are required before further progress can be made.

Secondly, and again like the rat, the viscacha has a very low milk citrate concentration $(<10-220 \mathrm{mg} / \mathrm{l})$, in contrast to the values obtained for the guinea-pig $(900-1600 \mathrm{mg} / \mathrm{l}$ : Peaker et al., 1975) and coypu (1060 mg/1: M. Peaker \& J. A. Goode, unpublished). It has been suggested that the low citrate content of rat's milk is related to the use of glucose for synthesis de novo of fatty acids in the mammary gland (see review by Holt, Muir, Ormrod, Zammit \& Peaker, 1980).

We thank Professor R. J. Harrison for facilities in the Department of Anatomy, Cambridge.

\section{References}

Chalk, P.A. \& Bailey, E. (1979) Changes in the ion content of milk during lactation in the rat. Comp. Biochem. Physiol. 63A, 619-625.

Fleet, I.R. \& Linzell, J.L. (1964) A rapid method of estimating fat in very small quantities of milk. $J$. Physiol., Lond. 175, 15-17P.

Fleet, I.R., Linzell, J.L. \& Peaker, M. (1972) The use of an autoanalyser for the rapid analysis of milk constituents affected by subclinical mastitis. Br. vet. J. 128, 297-300.
Goode, J.A. \& Taylor, J.C. (1974) A simple method of milking small animals. J. Physiol., Lond. 242, 5-7P.

Holt, C., Muir, D.D., Ormrod, I.H.L., Zammit, V.A. \& Peaker, M. (1980) Citrate in Milk. The Hannah Research Institute, Report 1979, pp. 63-69. The Hannah Research Institute, Ayr.

Jenness, R. (1974) The composition of milk. In Lactation, vol. 3, pp. 3-107. Eds B. L. Larson \& V. R. Smith. Academic Press, New York.

Linzell, J.L. (1967) The effect of very frequent milking 
and of oxytocin on the yield and composition of milk in fed and fasted goats. J. Physiol., Lond. 190, 333-346.

Linzell, J.L. \& Fleet, I.R. (1969) Accuracy of the micromethod of estimating milk fat concentration by high-speed centrifugation in capillary tubes. $J$. Dairy Sci. 52, 1685-1686.

Linzell, J.L. \& Peaker, M. (1971a) Intracellular concentrations of sodium, potassium and chloride in the lactating mammary gland and their relation to the secretory mechanism. J. Physiol., Lond. 216, 683700.

Linzell, J.L. \& Peaker, M. (1971b) Mechanism of milk secretion. Physiol. Rev. 51, 564-597.

Linzell, J.L., Peaker, M. \& Taylor, J.C. (1975) The effects of prolactin and oxytocin on milk secretion and on the permeability of the mammary epithelium in the rabbit. J. Physiol., Lond. 253, 547-563.

Mepham, T.B. \& Beck, N.F.G. (1973) Variation in the yield and composition of milk throughout lactation in the guinea pig (Cavia porcellus). Comp. Biochem. Physiol. 45A, 273-281.
Peaker, M. (1977) The aqueous phase of milk: ion and water transport. Symp. zool. Soc. Lond. 41, 113134.

Peaker, M. (1978) Ion and water transport in the mammary gland. In Lactation, vol. 4, pp. 437-462. Ed. B. L. Larson. Academic Press, New York.

Peaker, M. \& Taylor, J.C. (1975) Milk secretion in the rabbit: changes during lactation and the mechanism of ion transport. J. Physiol., Lond. 253, 527-545.

Peaker, M., Jones, C.D.R., Goode, J.A. \& Linzell, J.L. (1975) Changes in milk composition during lactation in the guinea pig, and the effect of prolactin. $J$. Endocr. 67, 307-308.

Weir, B.J. (1970) The management and breeding of some hystricomorph rodents. Lab. Anim. 4, 83-97.

Weir, B.J. (1971) The reproductive physiology of the plains viscacha, Lagostomus maximus. J. Reprod. Fert. 25, 355-363.

White, J.C.D. \& Davies, D.T. (1963) The determination of citric acid in milk. J. Dairy Res. 30, 171-189.

Received 13 January 1981 